\title{
Impacts of Monetary Policy on Commercial Banks' Profits: The Case of Vietnam
}

\author{
Thanh Nhan Nguyen ${ }^{1}$, Ngoc Huong $\mathrm{Vu}^{1}, \&$ Ha Thu Le ${ }^{2}$ \\ ${ }^{1}$ Banking Faculty, Banking Academy of Vietnam, Vietnam \\ ${ }^{2}$ Ha Thu Le, Banking Faculty, Banking Academy of Vietnam, Vietnam \\ Corresponding: Thanh Nhan Nguyen, Banking Faculty, Banking Academy of Vietnam, Vietnam. E-mail: \\ nhannt@hvnh.edu.vn
}

Received: December 5, 2016

Accepted: January 4, 2017

Online Published: July 25, 2017

doi:10.5539/ass.v13n8p32

URL: https://doi.org/10.5539/ass.v13n8p32

\begin{abstract}
This paper mainly concentrates on examining the impact of monetary policy on commercial banks' profit in Vietnam by using panel data regression. In our study, the data is collected from 20 commercial banks which were doing business in Vietnam's banking market, ranging from 2007 to 2014 in annually frequency. Monetary base (MB), discount rate (DIS) and required reserve ratio (RRR) are used as proxies for monetary policy. Profit before tax (PROFIT) is used to represent commercial banks' performance. The results show that there is a positive relationship between banks' profits and monetary policies. Among those chosen variables representing SBV's monetary policy, only MB has a significant positive impact on bank's profit at the significance level of $10 \%$. On this premise, the study recommends that MB should be one of the variables in the center of being concerned in the SBV's policies regarding the banking performance and stability.
\end{abstract}

Keywords: banks' perfomance, discount rate, monetary base, monetary policy, requied reserve ratio

\section{Introduction}

Monetary policy involves the use of monetary instruments to regulate or control the volume, the cost, the availability and the direction of money and credit in an economy to achieve some macroeconomic objectives such as price stability, full employment and sustainable economic growth (Mishkin, 2013). Banking system is considered as the most important channel of implementing monetary policy. The monetary instruments including discount rate, open market operation, reserve requirements, etc. do not affect economic activities directly. They influence economic activities through their effects on available resources in the banking sector. For instance, when the economy experiences inflationary pressure, the central bank can use contractionary monetary policy to stabilize the price level. This may be done by increasing the require reserve ratio and discount rate. This will then reduce the amount available to commercial banks for the purpose of credit facility and cost of borrowing will increase, loans will become expensive and people will borrow less. Aggregate spending will drop, so will investments. Moreover, due to higher interest rates, banks' deposits become more attractive as they offer better returns on savings. As a result, people tend to save more and spend less. On the contrary, if the objective is to increase the aggregate demand of the economy, the reserve ratio and discount rate may be reduced. It usually happens that as the cost of borrowing drops, it will become easier for people to afford loans, investments will then rise in the economy, which results in more employment opportunities because people start to spend more than usual.

The literature suggests that the monetary policy directly affects the bank performance. In order to make profit, for instance, commercial banks invest customers' deposits in various short-term and long-term investments. However, the core of such deposits is used for loans. Hence, the more loans and advances they extend to borrowers, the more profit they make (Solomon, 2012). When the central bank embarks on contractionary monetary policies, it reduces the available resources with the commercial banks. This consequently reduces their ability to make profit. On the other hand, expansionary monetary policies would have an opposite effect.

Vietnam has experienced unstable macro environment in the last ten years, which has led to changes in monetary policy. These changes have forced most of the commercial banks to shift the effects to their customers. Shifting these changes to customers may have an impact on the financial performance of the banks. This paper is, 
therefore, designed to examine the effect of monetary policy movements on Vietnam banking system's performance. The remaining part of this paper is divided into four sections. Some related literature is reviewed in the first section; the second section covers the methodology; discussion, conclusion and policy implication are presented in the fourth and the fifth sections, respectively.

\section{Monetary Policy in Vietnam}

The State Bank of Vietnam (SBV) is governed by the Law on the State Bank of Vietnam (2010). According to the law, the SBV is a body of the Vietnamese government and its governor is a member of the government. Decisions regarding monetary policy and its supervision are principal functions of the National Assembly and the government which is responsible for preparing a plan for monetary policy, including a projection of the annual inflation rate, and to submit it to the National Assembly for approval. Part of the role of the National Assembly is to set annual targets for the inflation rate in line with the state budget and economic growth objectives. The government is also closely involved in monetary policy by organizing the implementation of monetary policy, determining the amount of liquidity to be injected in the economy, and making report to a standing committee of the National Assembly.

The functions of the SBV include the preparation of the plan for monetary policy and the implementation of monetary policy as designed by the government. Regarding to the goals of the SBV, the SBV Law (1997) states that "the operations of the State Bank shall aim at the stabilization of the value of the currency, contribute to securing the safety of banking activities and the system of credit institutions, facilitate the socio-economic development in a manner consistent with the socialist orientation". The goals of monetary policy in this period are very broadly defined and a primary objective is not clearly identified. While in the SBV Law a hierarchy of goals is not established, the actual economic policy in Vietnam suggests that economic growth has been the de facto primary goal of the government. The multiplicity of goals without established hierarchy raises the risk of conflicting objectives.

However, this final goal has been changed in the 2010 Law on the SBV, which states that "the national monetary policy consists of national-level decisions on monetary affairs made by competent state agencies, including decisions on the objective of currency value stability which is denoted by the inflation rate and decisions on the use of tools and measures to obtain the set objective". The main objective of monetary policy now is only to stabilize currency's value and control inflation rate.

In the last two decades, the SBV has pursued a proactive and flexible monetary policy to stabilize the Vietnamese dong and the macro-economy as well as to achieve socio-economic development targets. This monetary policy is monetary targeting, in which the SBV focuses on the operational target of reserve money to adjust broad money as an intermediate target and affect the final goals of a stable currency, control over inflation, social stability, and improved living standards. The intuition for the monetary targeting framework is based on the long-run relationship between money and inflation and the assumption that money demand and the velocity of money are both stable.

The SBV announces annual targets for total liquidity (M2) and credit to the economy and uses monetary instruments including direct instruments (i.e. setting credit growth limitation, applying ceilling interest rates, and stipulating lending rates in prioritized areas) and indirect instruments (i.e. reserve requirements, refinancing policy and open market operations) to achieve this target. By closely monitoring the operation of credit institutions, the SBV observes changes in monetary and credit indicators of the whole system to adjust banks' credit growth targets in 6 months' time or sooner.

\begin{tabular}{|c|c|c|c|c|c|c|c|c|c|c|c|c|}
\hline & & 2006 & 2007 & 2008 & 2009 & 2010 & 2011 & 2012 & 2013 & 2014 & 2015 & 2016 \\
\hline \multirow{2}{*}{ th ( } & Target & $23-25$ & $20-23$ & 32 & $18-20$ & 25 & $\begin{array}{ll}15-16 \\
\end{array}$ & 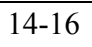 & $\begin{array}{ll}14-16 \\
\end{array}$ & 16-18 & $15-20$ & $15-20$ \\
\hline & Real & 33.6 & 46.1 & 20.3 & 29 & 33.3 & 12.4 & 22.4 & 18.5 & 17.6 & 16.2 & 18.4 \\
\hline \multirow{2}{*}{$\begin{array}{l}\text { Credit } \\
(\%)\end{array}$} & Target & $18-20$ & $17-21$ & 30 & 30 & 25 & 20 & $15-17$ & 12 & $12-14$ & $18-20$ & 18- 20 \\
\hline & Real & 25.4 & 53.9 & 25.4 & 37.5 & 31.2 & 4.4 & 8.9 & 12.5 & 14.1 & 18 & 18.3 \\
\hline
\end{tabular}

Source: State Bank of Vietnam

From 2006 to present, the implementation of monetary policy in Vietnam could be divided in four periods as follow:

Tightening Monetary Policy for Inflation Curb in the period of 2007-2008: From 2006 to mid-2017, the loosening monetary policy was applied to support the implementation of two Government's key tasks including economic growth and macro-economic stability. However, from the end of 2007, the SBV started monetary 
tightening with initial actions of increasing reserve requirements from $5 \%$ to $10 \%$ for deposits below twelve-month terms, and from $2 \%$ to $4 \%$ for deposits within twelve- and twenty-four-month terms. In the early of 2008, responding to a forecast of continuously high inflation, the SBV decided to further apply tightening monetary policy with an aim to limit credit growth rate below $30 \%$ and total broad money growth rate below $32 \%$ through using such instruments as (i) an increase of reserve requirements on all deposit terms; (ii) a mandatory issuance of the SBV's securities with total value of VND 20,300 billion which were not used for refinancing by SBV; (iii) an increase of base rates, refinancing rate and discount rate; (iv) a credit limitation and strict control of high-risked loans, particularly in stock investment and real estate.

Demand Stimulation in 2009: The Government flexibly changed the management target from inflation curb to prevention of economic downturn, resulted in a loosening monetary policy. The SBV managed and implemented monetary policy in this period through a variety of instruments including (i) deployment of interest rate support mechanism; (ii) reduction of base rate, discount rate and refinancing rate; (iii) reduction of reserve requirements on Vietnam Dong to 5\%; (iv) prepayment for SBV's VND 23,000 billion securities. The key open market operation was to buy securities.

Cautious Implementation of Monetary Policy to Stabilize and Maintain Growth Target in 2010: In 2010, the credit market in Vietnam was subject to tightening monetary policy in the early period and loosening policy in the later one. Monetary policy followed the direction of limited credit growth, risk control, improvement of credit quality and outstanding balance structure.

Macro Economic Stability, Inflation Curb and Proper Economic Growth Support in the period of 2011 to present: In early 2011, SBV reapplied the tightening monetary policy and conducted several actions to gain this target, including (i) requesting credit institutions to adjust the business plan in line with the credit growth objectives, tailor the credit structure, mobilize capitals on business and manufacturing development, reduce the speed and ratio of outstanding balance in lending for non-manufacturing area against the total outstanding balance to $22 \%$ as of June 30, 2011 and 16\% as of December 31, 2011; (ii) increasing the discount rate, refinancing rate and overnight lending rate in online interbank payment; (iii) purchasing securities in open market; (iv) requesting full compliance to credit limitation in the whole banking system with strict internal sanctions in each bank; (v) preparing and implementing restructure strategy for banking system with an aim to gradually improve effectiveness, reduce risks and enhance competitiveness of the banking system. In the early of 2012, the business and manufacturing sector was seen facing with difficulties. In the context of overall economic restructuring, the SBV has returned to loosening monetary policy until present. The continuous reduction of interest rates led to certain achievements, posing positive impacts on Vietnamese money market. Interest rates have fallen sharply, the average interbank exchange rate between VND and USD has been stabilized, the performance of credit institutions has improved and their liquidity has been guaranteed.

\section{Literature Review}

Monetary policy conducted by central banks always has a major impact on financial sector performance. This part is going to review a number of studies examining the relationship between monetary policy and commercial banks performance in advanced and developing economies.

\subsection{Advanced Economies}

There is widespread agreement that central banks' aggressive responses at the early stages of the crisis are highly likely to prevent a financial and economic recession. However, in recent years, concerns have been growing in the context that the negative effect of a low interest rate structure on bank profitability and the soundness of banking sector might decline the net benefits of such monetary accommodation. Surprisingly, the link between monetary policy and bank profitability is under-research, especially in advanced economies. Many papers have analyzed the link between bank profitability and business conditions but only few of them have produced results on the link between the interest rate structure and bank profitability.

Demirgüç-Kunt et al. (1999) were among the first to relate bank profits to macroeconomic indicators, such as real interest rates. They found that high real interest rates are associated with higher interest margins and profitability, especially in developing countries where demand deposits frequently pay below-market interest rates. Recent examples from this strand of literature include Albertazzi et al (2009), who used aggregate data for the banking sector in 10 OECD countries and found a significant relationship between net interest rate income and the yield curve slope. They also found a positive relationship between bank loss provisions and the short-term interest rate. Bolt et al (2012) obtained similar results using bank-level data and allowing for asymmetrical effects over the business cycle. 
A study by English (2002) examined the relationship between interest rate risk and bank interest rate margins in 10 industrialized countries. The paper showed that a steep yield curve has positive impact on interest margins as the average yield on bank assets is more closely related to long-term rates than the average yield on liabilities. Also, Alessandri et al. (2012) investigated the effects of interest rates on bank profitability using a panel data set in the United Kingdom from 1992 to 2009. They found that in the long run, both level and slope of the yield curve contribute positively to bank profitability. However, in the short run, an increase in short-term yields depresses interest margins, which is consistent with the presence of frictions affecting the repricing of banks' assets and liabilities in an asymmetric way.

In recent years, several developed countries including the United States, the United Kingdom, and Japan have adopted unconventional monetary policy as a way to help the economy out of recession. This policy is often assumed to provide stimulus to household and business spending, as well as to benefit banking system. However, instead of finding supporting evidence for the common perception that unconventional monetary policy actually helps banks, a study by Lambert et al. (2014) found some evidence for heightened medium-term risks, which is likely due to delayed balance sheet repair by banks. In particular, the authors proved that unexpected monetary policy easing tends to increase bank medium-term credit risk in the United States, the Euro area, and the United Kingdom. Moreover, unconventional monetary policy measures have ambiguous effects on banks' profitability. These findings are the result of two sets of analyses: an event study on bank stock valuation and credit risk, and panel regressions on bank level measures of profitability, risk taking, and balance sheet repair.

With the objective of investigating how monetary policy affects bank profitability, Borio et al (2015) used data of 109 large international banks headquartered in 14 major advanced economies for the period $1995-2012$. The authors considered the impact of changes in the interest rate structure, i.e. level of short-term rate and yield curve slope, on all main income statement components - net interest income, non-interest income and bank loss provisions - as well as on overall profitability, measured by ROA. They then found a positive relationship between the level of short-term rates and the slope of the yield curve (i.e. the interest rate structure), on the one hand, and bank profitability - ROA - on the other. This suggests that the positive impact of the interest rate structure on net interest income dominates the negative one on loan loss provisions and on non-interest income. The paper also found that the effect is stronger when the interest rate level is lower and the slope is less steep, i.e. non-line arities are present. All this suggests that, over time, unusually low interest rates and an unusually flat term structure erode bank profitability.

\subsection{Developing Economies}

The impact of monetary policy on commercial banks' profitability in India was investigated by Punita et al (2006) for the period from 1995 to 2000. The variables representing monetary policy include banks rate, lending rates, cash reserve ratio and statutory ratio. The paper then found that lending rate exacts positive and significant impact on banks' profitability, while bank rate, cash reserve ratio and statutory ratio have significant and negative influence on this variable. This conclusion was the same when lending rate, bank rate, cash reserve ratio and statutory ratio were pooled to explain the relationship between banks' profitability and monetary policy instruments in the private sector.

More particularly, Younus et al. (2009) examined the impact of monetary policy instrument, namely Statutory Liquidity Requirement (SLR), on bank credits in Bangladesh. Using descriptive analysis techniques, they found that SLR has a negative impact on bank credits and investments especially prior to the 1990s. SLR and Cash Reserve Requirement (CRR) were found to be significant tools of reducing inflation and both used in the situation of drastic imbalance resulting from major shocks. The authors also concluded that Bangladesh Bank has used open market operations more frequently than SLR and bank rate as instruments of monetary policy due to its market oriented approach.

A study by Amaliawiati et al. (2013) focused on the relationship between BI rate, i.e. one of the monetary policy of the Indonesian Central Bank interest rate, and the profitability of conventional commercial banks listed on the Indonesia Stock Exchange from 2005 to 2012. By using ROA and NIM as the proxy of profitability, the paper concluded that BI rate has a significantly negative effect on ROA, but it does not show a statistically significant impact on NIM. Furthermore, based on the semi-partial correlation coefficients, BI rate is proved to have great influence in determining ROA ranks, while Operational Cost of Operational Income is of great importance in determining NIM of commercial banks in Indonesia.

Having the same method by using interest rate to represent monetary policy, but ROA and ROE to represent banking sector performance, Zaman et al. (2014) investigated the casual relationship between interest rate imposed by the Pakistan central bank and banking sector performance during the period between 2007 and 2011. 
By taking firm size as the control variable because of its significant effect on banks' performance, the study found that monetary policy, which is represented by interest rate, has a significant inverse impact on banks' performance, which is measured by ROA and ROE.

There are numerous studies examining the impact of monetary policy on commercial banks' performance in Nigeria. A study by Akanbi et al. (2012) employed three commercial banks (i.e. the first generation banks) in the Nigerian financial system to investigate the impact of monetary policy on commercial banks from 1992 to 1999. The results showed that an increase in interest rate will lead to a decrease in the lending rate, while liquidity ratio and cash ratio have a statistically significant impact on the selected banks' profits, which confirms the authors' expectation. Looking more closely at bank credits, a study by Ajayi et al. (2012) showed that monetary policy is ineffective to stimulate credits in the long-run, and that bank rate, inflation rate and exchange rate are positively related to bank credits, but liquidity ratio and cash reserves ratio are negatively related to total credit of the banks. The study was carried out during the period from 1978 to 2008, and Engle-granger two-step co-integration approach was employed.

To investigate the effect of monetary policy on the Nigerian Deposit Money Bank System, Omankhanlen (2014) employed total loans and advances as dependent variable, and liquidity ratio, cash reserve ratio, monetary policy rate, and average exchange rate as independent variables. He then concluded that monetary policy rate reveals the most significant effect on commercial bank loans and advances during the period under study.

By using interest rate and money supply as proxies for monetary policy, and profit before tax to represent commercial banks' performance in a micro-panel analysis, Akomolafe et al. (2015) found that there is a positive relationship between banks' profits and monetary policies in Nigeria. The study covers a period from 2003 to 2013. Another study by Ekpung et al. (2015) also examined the effect of monetary policy on banking sector performance from 1970 to 2006 . However, the study uses banks' deposit liabilities to represent banks' performance and indicates that monetary policy has a significant effect on banks' deposit liabilities. In particular, deposit rate and minimum discount rate have a negative influence on banks' deposit liabilities, whereas exchange rate has a positive and significant impact on this variable. More particularly, Udeh (2015) investigated the impact of monetary policy instruments on profitability of commercial banks in Nigeria using the Zenith Bank Plc experience from 2005 to 2012. The study discovered that cash reserve ratio, liquidity ratio and interest rate have an insignificant impact on the profit before tax of Zenith Bank Plc. However, minimum rediscount rate is found to have significant effect on this variable. The author then concluded that a number of monetary policy instruments have an insignificantly impact on profitability of commercial banks in Nigeria, and thus management of commercial banks should look beyond monetary policy instruments to enhance their profits.

\section{Methodology}

\subsection{Data Description}

The paper is to assess the relationship between monetary policy movements and the banking system's performance. The data is collected from 20 commercial banks which were doing business in Vietnam's banking market, ranging from 2007 to 2014 in annually frequency. The total number of observations is 157.

The dependent variable which represents the bank's performance is bank's profit, which has been chosen by many previous researchers including Akomolafe et al. (2015), Ajayi and Atanda (2012).

Table 1. Internal Independent Variables

\begin{tabular}{ccc}
\hline Internal Independent Variables & Description & Formula \\
\hline CRE & Credit growth & CRE $=\frac{\text { Credit }_{t}-\text { Credit }_{t-1}}{\text { Credit }_{t-1}}$ \\
LDR & Loan-to-deposit ratio & LDR $=\frac{\text { Total } \text { of Loan Value }}{\text { Customers'Deposits }^{\prime}}$ \\
LIQ & Liquidity ratio & LIQ $=\frac{\text { Liquid Assets }}{\text { Customers'Deposits }^{\prime}}$
\end{tabular}

Note: Liquid Assets include cash, foreign currencies, gold and gemstones.

Source: Nguyen et al. (2016)

The independent variables used as the proxies for SBV monetary policy are monetary base (MB), discount rate (DIS) and required reserve ratio (RRR). These variables are not only to provide full analysis of the effect of 
monetary policy on Vietnam's banking performance, but also help to find the most effective monetary policy tool affecting the performance of banking system. Besides monetary policy factors, the remaining determinants of bank's performance can be divided in internal and external factors. Internal factors of bank's performance can be defined as those factors that are influenced by the bank's management policy objectives and decisions. Credit growth (CRE), loan-to-deposit ratio (LDR), and liquidity ratio (LIQ) are used as the proxies for internal factors to reflect characteristics of commercial bank in Vietnam. These internal independent variables are presented in the Table 1.

External determinants of bank's performance are concerned with those factors which are not influenced by specific bank's decisions and policies, but by events outside the influence of the bank. Economic growth (GDP) and inflation (measured by inflation in term of CPI) are used as the proxies for external factors to reflect Vietnam macroeconomic condition.

Most data are taken from Annual Report of Vietnam commercial banks, General Statistic Office of Vietnam and State bank of Vietnam. All variables and statistic summary of these variables' time series are presented in the Table 2 .

Table 2. Descriptive Statistics of input variables

\begin{tabular}{cccccccc}
\hline Variables & Mean & Median & Maximum & Minimum & Std. Dev. & Skewness & Obs. \\
\hline PROFIT & 1281398 & 732022 & 6259367 & 9710 & 1391510 & 1.65 & 157 \\
$\log ($ PROFIT $)$ & 5.82 & 5.86 & 6.80 & 3.99 & 0.56 & -0.46 & 157 \\
MB & 532029544 & 481215455 & 825687422 & 315711820 & 165508717 & 0.43 & 157 \\
$\log$ (MB) & 8.71 & 8.68 & 8.92 & 8.50 & 0.14 & 0.13 & 157 \\
RRR & 0.05 & 0.04 & 0.10 & 0.03 & 0.03 & 1.49 & 157 \\
DIS & 0.07 & 0.06 & 0.11 & 0.05 & 0.03 & 0.57 & 157 \\
GDP & 0.06 & 0.06 & 0.07 & 0.05 & 0.01 & 0.81 & 157 \\
CPI & 0.11 & 0.09 & 0.23 & 0.04 & 0.07 & 1.31 \\
CRE & 0.38 & 0.25 & 2.34 & -0.32 & 0.44 & 1.85 \\
LDR & 0.87 & 0.85 & 2.52 & 0.24 & 0.26 & 157 \\
LIQ & 0.30 & 0.30 & 0.71 & 0.07 & 0.14 & 0.70 \\
\hline
\end{tabular}

Source: Nguyen et al. (2016)

\subsection{Model Specification and Result}

Based on the presented data, the entity fixed regression will be run on the following equation:

$$
\begin{aligned}
\log \left({\text { PROFIT })_{i t}=}\right. & \beta_{0}+\beta_{1} C R E_{i t}+\beta_{2} L D R_{i t}+\beta_{3} L I Q_{i t}+\beta_{4} \log (M B)_{t}+\beta_{5} R R R_{t}+\beta_{6} D I S_{t}+\beta_{7} G D P_{t}+\beta_{8} C P I_{t} \\
& +\mu_{i}+\varepsilon_{i t}
\end{aligned}
$$

The equation is applied to examine the determinants of banking profit. Because profit and monetary base (MB) data is number, while other variables in the equation are all presented as ratios. Therefore, these two variable will be presented as the logarithm. Specifically, logarithm of banking profit will be regressed by independent variables including the logarithm of MB.

To avoid the problem of multi-collinearity, the tests on correlations among dependent variables are conducted before the panel data regression is run. The test result is presented in table 3. This table shows that there is no significant correlation among those dependent variables since most of the calculated correlations are less than 0.5. Therefore, it can be concluded that the model does not contain a significant problem of multi-collinearity. Thus, the results from the regression model would be valuable. Moreover, the equation is run by the fixed effect regression with robust standard errors that deals with the problem of heteroskedasticity which may be arisen.

Table 3. Correlations among dependent variables

\begin{tabular}{ccccccccc}
\hline & $\log (\mathrm{MB})$ & RRR & DIS & GDP & CPI & CRE & LDR & LIQ \\
\hline $\log (\mathrm{MB})$ & 1 & & & & & & & \\
RRR & -0.7678 & 1 & & & & & & \\
DIS & -0.0696 & -0.0238 & 1 & & & & & \\
GDP & -0.5308 & 0.2817 & -0.2174 & 1 & & & & \\
CPI & -0.4095 & 0.5073 & 0.7818 & 0.1136 & 1 & & & \\
\hline
\end{tabular}




\begin{tabular}{lllllllll}
\hline CRE & -0.4389 & 0.1205 & -0.2760 & 0.1308 & -0.1587 & 1 & & \\
LDR & -0.2455 & 0.0422 & -0.0349 & 0.2032 & 0.0318 & 0.1765 & 1 & \\
LIQ & -0.3090 & 0.2170 & -0.0154 & 0.3132 & 0.1188 & 0.0297 & -0.2435 & 1 \\
\hline
\end{tabular}

Source: Nguyen et al. (2016)

The panel data regression with fixed effect on entities would be chosen since the banks or entities' property can be significant factors driving the banking performance and more specifically, banking profit. Besides the main, available and measurable internal factors that have already been chosen, other important bank's characteristics may be omitted. As a matter of fact, the whole banks' characteristics are difficult to be fully captured; therefore the fixed effect model on entities by generating dummy variables on each bank can deal with this difficulty and avoid a serious problem in running regression. The result of fixed effect is shown in the Table 4.

Table 4. Fixed effect regression result

\begin{tabular}{cccc}
\hline \multirow{2}{*}{ Independent Variables } & \multicolumn{2}{c}{ Dependent Variables: $\log$ (PROFIT) } & p-value \\
\cline { 2 - 4 } & Coefficients & Robust S.E. & 0.00 \\
\hline $\log (\mathrm{MB})$ & -5.009 & 1.213 & 0.00 \\
RRR & -107.0 & 23.43 & 0.00 \\
DIS & -54.73 & 16.01 & 0.00 \\
GDP & -50.06 & 16.62 & 0.00 \\
CPI & 34.95 & 8.965 & 0.03 \\
CRE & 0.409 & 0.185 & 0.08 \\
LDR & -0.443 & 0.250 & 0.08 \\
LIQ & 1.200 & 0.682 & \\
R-squared & 0.8509 & & \\
Test on Fixed Effect & & \\
F-Statistics & 75.91 & &
\end{tabular}

Source: Nguyen et al. (2016)

\subsection{Specification Tests}

To test the validity of this fixed effect model, the F-test on the entity fixed effects is conducted. From the result above, $\mathrm{p}$-value which is less than 0.01 shows that the null hypothesis that the fixed effect is non-valid can not be rejected at the significance level of $1 \%$. In other words, at the confidential level of $99 \%$, the fixed effect is significant in this panel model. Besides, R-squared of this model is calculated to be $85.09 \%$, greater than $50 \%$, showing the fitness of the panel regression. For panel data, there are two common regression methods with fixed effect and random effects. The advantage of fixed effect regression is that it captures all time-invariant characteristics of entity that can affect the dependent variable, which is banking credit in this case. In addition to the persuasiveness of the applied regression in this paper as the fixed effect panel data regression, the Hausman test also is conducted and the result is presented in the table. The Chi-square statistic of Hausman test is negative showing that the null hypothesis in which the random effect regression can replace fixed effect regression can not be rejected. In other words, the results in this fixed effect regression is valid and can not be replaced by alternative mode of regression, particularly the random effect regression.

\section{Discussion}

The regression result reveals that all three tools representing the SBV's monetary policy have significant impact on Vietnamese banking system's profit at $1 \%$ level. While discount rate (DIS) and reserve requirement ratio (RRR) show negative relationship with banking profit, as same as the theory, MB has a significant negative impact on banks' profits, which is not consistent with the fact that when monetary policy is expanded, the banking profit is supposed to be grown. However, by the reality of the SBV's monetary policy implementation and the status of Vietnamese banking system, while tightened monetary policy is conducted with the rising of discount rate and reserve requirement ratio, the money base (MB) still can be increased for the systematic liquidity of Vietnamese banking system. This increase in MB does not conflict to the direction of monetary policy conduction by the SBV; more importantly this operation support for the banking system to avoid an unnecessary policy shock. Therefore, the empirical result confirmed the status of Vietnamese banking system in 
the context of the SBV's monetary policy implementation that banking profit is negatively associated with tightened monetary policy and reversely this value is positive related to the monetary expansionary, which is consistent with the result from Akomolafe et al. (2015). Indeed, the empirical result showed that the impacts of DIS and RRR on banking profit are much greater than the theoretically inconsistent impact of MB; at the significance level of $1 \%$, the coefficients of DIS, RRR, and MB are $-54,-107$, and -5 , respectively. Moreover, through this estimated coefficient, the monetary tools having a great impact on Vietnam's commercial banking profit is reserve requirement ratio.

Among the internal factors, the banking credit growth is shown to have statistically significant effect on the banking profit. Specifically, at 5\% level, the CRE's coefficient is regressed to be approximately 0.41 , which means that an 1 percentage point increase in credit growth of a commercial bank in Vietnam raises that bank's profit by $40 \%$. This empirical result is consistent with the fact that the main business of Vietnam's commercial banks is giving loan. In other words, banking credit is the major part of the bank' asset and credit growth unquestionably is the main source of the banking profit. The positive impact of Credit Growth on banking profit is consistent in both theoretical and empirical terms. The study of Adeusi et al (2014) also had a similar conclusion when they found out that credit risk is one of the main determinants of Nigerian banking system's profit.

Moreover, there is a significant coefficient being found on the bank's liquidity ratio. Specifically, at the $10 \%$ level, the estimated coefficient on LIQ is 1.2. This implies that liquidity is also one of the factors driving the profit of Vietnam's commercial banks. As a matter of fact, banking liquidity not only supports the banks to deal with the variety of risks but also shows the reputation and reliance of banks in the case of Vietnam. Therefore, the statistically significant and positive relationships of LIQ and $\log$ (PROFIT) confirms this status of Vietnam's commercial banking system.

With respect to the external factors, both economic growth and inflation rate are shown to have significant impacts on the banking performance. At the confidential level of $99 \%$, Vietnam's inflation has a positive influence on the bank' profit. This finding is consistent with the theory that high inflation reduce real interest rate, therefore credit demand is increased and so is banking profit.

\section{Conclusion and Policy Implication}

This paper has revealed the positive significant causal relationship between monetary policy and the commercial banks' performance in Vietnam. This finding is consistent with the majority of previous studies including Ajayi and Atanda (2012), Akomolafe et al (2015) and Borio et al (2015).

Other banking profit's determinants including Credit Growth and Liquidity are also found. They are the main internal drivers of banking profit. Moreover, the macroeconomic factors including economic growth and inflation is shown to have significant influence on banking system's performance.

Some policy implications have been drawn from this study. The first implication is that because monetary policy is found to have significant impact on banking system's performance. Every movement in the monetary policy of the SBV should concern about the soundness of the domestic banking system. The second implication is that SBV should pay more attention on bank's liquidity since liquidity ratio has been proved to be significant in driving the banking performance. Not only that, improving banking liquidity also promote the stability and soundness of Vietnamese financial system. The last implication is that because the Vietnamese banking system's performance is influenced considerably by the status of the macro economy, the cooperation between monetary policy and other macroeconomic policies, particularly fiscal policy is needed for the improvement of Vietnamese banking system's performance and the soundness of the whole financial system.

\section{References}

Adeusi, S. O., Kolapo, F. T., \& Aluko, A. O. (2014). Determinants of commercial banks' profitability panel evidence from Nigeria. International Journal of Economics, Commerce and Management, 2(12), 1-18

Ajayi, F. O., \& Atanda, A. A. (2012). Monetary policy and Bank performance in Nigeria: A two-step cointegration approach. African Journal of Scientific Research, 9(1).

Akanbi, T. A., \& Ajagbe, F. A. (2012). Analysis of monetary policy on commercial banks in Nigeria. African Journal of Business Management, 6(51), 12038-12042. https://doi.org/10.5897/AJBM11.1843

Akomolafe, K. J., Danladi, J. D., Babalola, O., \& Abah, A. G. (2015). Monetary policy and Commercial banks' performance in Nigeria. Public Policy and Administration Research, 5(9).

Albertazzi, U., \& Gambacorta, L. (2009). Bank Profitability and the Business cycle. Journal of Financial 
Stability, 5(4), 393-409. https://doi.org/10.1016/j.jfs.2008.10.002

Alessandri, P., \& Nelson, B. (2012). Simple banking: Profitability and the Yield curve. Working Paper No. 452, Bank of England. https://doi.org/10.2139/ssrn.2093394

Amaliawiati, L., \& Winarso, E. (2013). The influence of Monetary policy (BI rate) on Profitability of Commercial banks in Indonesia, $10^{\text {th }}$ Ubaya International Annual Symposium on Management

Bolt, W., de Haan, L., Hoeberichts, M., van Oordt, M. R. C., \& Swank, J. (2012). Bank Profitability during Recessions. Journal of Banking and Finance, 36(9), 2552-2564. https://doi.org/10.1016/j.jbankfin.2012.05.011

Borio, C., Gambacorta, L., \& Hofmann, B. (2015). The influence of monetary policy on bank profitability. BIS Working Papers No. 514.

Demirgüç-Kunt, A., \& Huizinga, H. (1999). Determinants of Commercial bank Interest margins and Profitability: Some International evidence. The World Bank Economic Review, 13(2), 379-408. https://doi.org/10.1093/wber/13.2.379

Ekpung, G. E., Udude, C. C., \& Uwalaka, H. I. (2015). The impact of monetary policy on the banking sector in Nigeria. International Journal of Economics, Commerce and Management, United Kingdom, 3(5).

English, W. B. (2002). Interest rate risk and bank net interest margins. BIS Quarterly Review, 67-82.

Lambert, F., \& Ueda, K. (2014). The Effects of Unconventional Monetary Policies on Bank Soundness. IMF Working Paper No. 14/152. https://doi.org/10.5089/9781498363563.001

Mishkin, F. S. (2013). The Economics of money, banking, and financial markets (10th ed.). Pearson Education, New York.

Omankhanlen, A. E. (2014). The effect of Monetary policy on the Nigerian Deposit Money Bank System. International Journal of Sustainable Economies Management, 3(1), 39-52. https://doi.org/10.4018/ijsem.2014010104

Punita, R., \& Somaiya, K. J. (2006). Monetary policy: Its impact on the Profitability of Banks in India, International Business \& Economics Research Journal, 5(3).

Udeh, S. N. (2015). Impact of Monetary policy instruments on Profitability of Commercial banks in Nigeria: Zenith Bank Experience. Research Journal of Finance and Accounting, 6(10).

Younus, S., \& Mahfuza, A. (2009). The SLR as a Monetary Policy Instrument in Bangladesh. IMF Occasional Paper No. 234, Washington, International Monetary Fund.

Zaman, R., Arslan, M., Sohail, M., \& Malik, R. K. (2014). The impact of Monetary policy on Financial performance: Evidence from Banking sector of Pakistan. Journal of Basic and Applied Scientific Research, 4(8), 119-124. https://doi.org/10.2139/ssrn.2515079

\section{Copyrights}

Copyright for this article is retained by the author(s), with first publication rights granted to the journal.

This is an open-access article distributed under the terms and conditions of the Creative Commons Attribution license (http://creativecommons.org/licenses/by/4.0/). 